\title{
Influence of Chloride and Nitrogen Form on Rhizoctonia Root and Crown Rot of Table Beets
}

\author{
Wade H. Elmer, The Connecticut Agricultural Experiment Station, P.O. Box 1106, New Haven 06504
}

\begin{abstract}
Elmer, W. H. 1997. Influence of chloride and nitrogen form on Rhizoctonia root and crown rot of table beets. Plant Dis. 81:635-640.

The effect of $\mathrm{NaCl}$ combined with $\mathrm{Ca}\left(\mathrm{NO}_{3}\right)_{2}$ or $\left(\mathrm{NH}_{4}\right)_{2} \mathrm{SO}_{4}$ was examined on table beets (Beta vulgaris) in the presence and absence of Rhizoctonia solani (anastomosis group 2-2), the cause of Rhizoctonia root and crown rot. Transplants of cvs. Detroit Dark Red and Early Wonder grown in the greenhouse in infested soils and fertilized with $\mathrm{Ca}\left(\mathrm{NO}_{3}\right)_{2}(10 \mathrm{mmol}$ of $\mathrm{N})$ were $32 \%$ larger in dry weight than plants treated with $\left(\mathrm{NH}_{4}\right)_{2} \mathrm{SO}_{4}(10 \mathrm{mmol}$ of $\mathrm{N})$. In noninfested soils, a $17 \%$ increase in dry weights was observed for plants treated with $\mathrm{Ca}\left(\mathrm{NO}_{3}\right)_{2}$ compared to plants that were fed $\left(\mathrm{NH}_{4}\right)_{2} \mathrm{SO}_{4}$. When $\mathrm{NaCl}(0.17 \mathrm{mmol})$ was applied, the mean dry weights increased $40 \%$ in noninfested soil and $12 \%$ in infested soil compared to plants that received no $\mathrm{NaCl}$. No significant interaction occurred between $\mathrm{N}$ fertilizer and $\mathrm{NaCl}$ in greenhouse trials. However, in field soils infested with $R$. solani, $\mathrm{NaCl}(560 \mathrm{~kg} / \mathrm{ha})$ combined with $\left(\mathrm{NH}_{4}\right)_{2} \mathrm{SO}_{4}(112$ $\mathrm{kg}$ of $\mathrm{N}$ per ha) produced 26 to $47 \%$ more root yield than when $\left(\mathrm{NH}_{4}\right)_{2} \mathrm{SO}_{4}$ was used alone. In the absence of $\mathrm{NaCl}, \mathrm{Ca}\left(\mathrm{NO}_{3}\right)_{2}$ suppressed disease more than $\left(\mathrm{NH}_{4}\right)_{2} \mathrm{SO}_{4}$, but adding $\mathrm{NaCl}$ to $\mathrm{Ca}\left(\mathrm{NO}_{3}\right)_{2}$ did not increase yield more than $\mathrm{Ca}\left(\mathrm{NO}_{3}\right)_{2}$ alone. The $\mathrm{Cl}$ salts $\mathrm{KCl}, \mathrm{CaCl}_{2}$, and $\mathrm{MgCl}_{2}$ did not significantly differ from $\mathrm{NaCl}$ in their ability to increase the dry weight of beets grown in infested soils. Leaf and root analyses revealed that $\left(\mathrm{NH}_{4}\right)_{2} \mathrm{SO}_{4}$ applications increased $\mathrm{N}, \mathrm{P}, \mathrm{S}$, and $\mathrm{Mn}$ in tissue more than $\mathrm{Ca}\left(\mathrm{NO}_{3}\right)_{2}$ applications. Applying $\mathrm{NaCl}$ increased tissue levels of $\mathrm{Na}, \mathrm{Cl}$, and $\mathrm{Mn}$ more than in plants that were not fed $\mathrm{NaCl}$. All of the $\mathrm{Cl}$ salts had the effect of increasing concentrations of $\mathrm{Cl}$ and $\mathrm{Mn}$ in the plant. There was no evidence that the $\mathrm{Na}$ ion was disease suppressive. Chloride, however, may be of use in disease management of Rhizoctonia root and crown rot of table beets.
\end{abstract}

Rhizoctonia solani Kühn, the anamorph of Thanatephorus cucumeris (A.B. Frank) Donk, has become a destructive pathogen of table beets (Beta vulgaris L.) in the northeastern United States (1,25). Beet plants can be infected at any time during the production cycle, and all tissues are susceptible to $R$. solani. Symptoms of dampingoff, root and crown rot, dry rot cankers, and a foliage blight known as pocket rot syndrome all are caused by $R$. solani (1, 25,33). Control of $R$. solani on table beets has been extremely difficult because no highly resistant cultivars are available, and effective chemicals have not been cleared for use on table beets. The threat to beet production also increased with the discovery that the teleomorph, T. cucumeris, is contributing wind-blown inoculum in the form of basidiospores (2).

Although it is well documented that the nutritional status of a plant can influence its susceptibility to disease $(4,11,12,19)$, manipulating fertilizers as a strategy for managing disease has not gained wide ac-

Corresponding author: W. H. Elmer

E-mail: whelmer@caes.state.ct.us

Accepted for publication 28 February 1997.

Publication no. D-1997-0404-04R

(C) 1997 The American Phytopathological Society ceptance. This may be due to a lack of understanding of which fertilizers are suppressive to disease and to inconsistent responses from year to year. The failure of certain fertilizers to affect disease also may be due to a lack of understanding of how fertilizers affect the uptake and distribution of other elements that may be more crucial in disease suppression.

$B$. vulgaris is very tolerant of saline conditions (33), and single applications of $\mathrm{NaCl}$ improve growth and yield in both sugar and table beets $(6,15)$. Hammer and Beene (15) found that when using muck soils in Michigan adding $\mathrm{NaCl}$ with $\mathrm{KCl}$ stimulated growth and yield of beets and Swiss chard. Durrant et al. (6) found $\mathrm{NaCl}$ increased leaf area and sugar beet yield and was most effective during periods of drought. In New York State, applications of $\mathrm{NaCl}$ at $560 \mathrm{~kg} / \mathrm{ha}$ once were recommended in beet production to enhance growth and suppress weeds (G. Abawi, personal communication).

Greenhouse studies have shown that beet seedlings were more susceptible to disease by $R$. solani when treated with $\mathrm{NH}_{4}-\mathrm{N}$ as opposed to $\mathrm{NO}_{3}-\mathrm{N}$ (4). However, conditions in the field may differ enough to question whether these $\mathrm{N}$ fertilizers would differ in their effect on Rhizoctonia root and crown rot of table beets.

A combination of chloride salts with different forms of nitrogen has proven sup- pressive to root diseases on asparagus (7), celery (29), and several grain crops (18). The combined effects of chloride and $\mathrm{N}$ form on $R$. solani on beets needs to be examined. The objective of this paper was to compare the combined effects of $\mathrm{NaCl}$ and $\left(\mathrm{NH}_{4}\right)_{2} \mathrm{SO}_{4}$ or $\mathrm{Ca}\left(\mathrm{NO}_{3}\right)_{2}$ on growth, disease, and mineral composition of table beets. A second objective was to compare different sources of chloride salts.

\section{MATERIALS AND METHODS}

Greenhouse studies. A highly pathogenic isolate of $R$. solani (anastomosis group 2-2) was obtained from the USDA Sugar Beet Laboratory, Michigan Sate University, East Lansing. Millet inoculum was prepared by autoclaving $100 \mathrm{~g}$ of Japanese millet with $100 \mathrm{ml}$ of distilled $\mathrm{H}_{2} \mathrm{O}$ in 1-liter flasks for $1 \mathrm{~h}$ on two consecutive days. Flasks were seeded with three agar plugs colonized by $R$. solani and shaken twice a week to promote rapid and uniform colonization. After 3 weeks, the colonized millet was shaken into sterile paper bags, dried at room temperature, and ground to pass through a 0.5 -mm sieve.

Seeds of table beet cvs. Detroit Dark Red and Early Wonder (Hart Seed Co., Wethersfield, CT) were sown in 36-cell plastic trays filled with ProMix BX (Premier Brand, New Rochelle, NY). After 4 weeks, seedlings were thinned to one plant per cell and transplanted into $10-\mathrm{cm}$ square plastic pots filled with 2 parts ProMix BX potting mix and 1 part sand. The mix had the following properties: $\mathrm{pH}=6.5$, bulk density $=0.7$ g/liter, $\mathrm{NO}_{3}-\mathrm{N}=3.0 \mu \mathrm{g} / \mathrm{g}, \mathrm{NH}_{4}-\mathrm{N}=0.0$ $\mu \mathrm{g} / \mathrm{g}, \mathrm{PO}_{4}-\mathrm{P}=100 \mu \mathrm{g} / \mathrm{g}$, exchangeable $\mathrm{K}^{+}$ $=6.0 \mathrm{meq} / 100 \mathrm{~g}$, exchangeable $\mathrm{Ca}^{+2}=8.0$ meq/100 g, exchangeable $\mathrm{Mg}^{+2}=2.5 \mathrm{meq} /$ $100 \mathrm{~g}$, and exchangeable $\mathrm{Cl}^{-}=0.8 \mathrm{meq} /$ $100 \mathrm{~g}$. The soil in half the pots was infested previously with $0.2 \mathrm{~g}$ of the millet inoculum per liter of soil mix. Uncolonized autoclaved millet that was similarly prepared was mixed into soil that filled the remaining pots to serve as noninfested controls.

One plant was transplanted into each pot, and the fertilizer treatments were applied immediately. Hoagland's solution (17) was modified where the $\mathrm{N}$ form was altered accordingly. The base stock had $2 \mathrm{mmol}$ of $\mathrm{MgSO}_{4}, 1 \mathrm{mmol}$ of $\mathrm{K}_{2} \mathrm{HPO}_{4}$, and $1 \mathrm{ml}$ of the Hoagland's trace elements per liter of $\mathrm{H}_{2} \mathrm{O}$. To this, $\left(\mathrm{NH}_{4}\right)_{2} \mathrm{SO}_{4}$ or $\mathrm{Ca}\left(\mathrm{NO}_{3}\right)_{2}$ was added to yield $10 \mathrm{mmol}$ of $\mathrm{N}$. Each $\mathrm{N}$ stock was divided in two, and half was treated with $\mathrm{NaCl}$ to yield $0.17 \mathrm{mmol}$ of $\mathrm{NaCl}$ 
(1\%, wt/vol). Pots received $100 \mathrm{ml}$ of each fertilizer treatment once a week and were watered with deionized water to keep soil moist. Therefore, 16 treatments (two cultivars by two $\mathrm{N}$ forms by two $\mathrm{NaCl}$ treatments by two inoculum treatments) were arranged randomly on a greenhouse bench under high-intensity sodium-vapor lights. The experiment was conducted two times, with five or six replicates per treatment. The experiment also was repeated twice, with six replicates in sand culture that had been infested with and without the millet inoculum.

Table 1. The influence of $\mathrm{N}$ form combined with $\mathrm{NaCl}$ on disease ratings and dry weights of two beet cultivars grown in noninfested soil or soil infested with Rhizoctonia solani (anastomosis group 2-2)

\begin{tabular}{|c|c|c|c|c|}
\hline \multirow[b]{2}{*}{ Treatment $^{\mathrm{a}}$} & \multicolumn{2}{|c|}{ Experiment I } & \multicolumn{2}{|c|}{ Experiment II } \\
\hline & Disease rating $^{\mathrm{b}}$ & Dry weight (g) & Disease rating & Dry weight (g) \\
\hline \multicolumn{5}{|l|}{ Noninfested soil } \\
\hline$\left(\mathrm{NH}_{4}\right)_{2} \mathrm{SO}_{4}$ & $\ldots$ & $0.59^{\mathrm{c}}$ & $\ldots$ & 1.01 \\
\hline$\left(\mathrm{NH}_{4}\right)_{2} \mathrm{SO}_{4}+\mathrm{NaCl}$ & $\ldots$ & 1.12 & $\ldots$ & 1.22 \\
\hline $\mathrm{Ca}\left(\mathrm{NO}_{3}\right)_{2}$ & $\ldots$ & 1.31 & $\ldots$ & 1.08 \\
\hline $\mathrm{Ca}\left(\mathrm{NO}_{3}\right)_{2}+\mathrm{NaCl}$ & $\ldots$ & 1.53 & $\ldots$ & 1.44 \\
\hline \multicolumn{5}{|l|}{ Infested soil } \\
\hline$\left(\mathrm{NH}_{4}\right)_{2} \mathrm{SO}_{4}$ & 3.6 & 0.23 & 3.1 & 0.76 \\
\hline$\left(\mathrm{NH}_{4}\right)_{2} \mathrm{SO}_{4}+\mathrm{NaCl}$ & 2.5 & 0.39 & 2.6 & 0.81 \\
\hline $\mathrm{Ca}\left(\mathrm{NO}_{3}\right)_{2}$ & 2.1 & 0.54 & 1.8 & 1.11 \\
\hline $\mathrm{Ca}\left(\mathrm{NO}_{3}\right)_{2}+\mathrm{NaCl}$ & 2.0 & 0.67 & 2.1 & 1.09 \\
\hline \multicolumn{5}{|l|}{$\operatorname{ANOVA}(P)^{\mathrm{d}}$} \\
\hline \multicolumn{5}{|l|}{ Source } \\
\hline $\mathrm{N}$ form & 0.009 & 0.002 & 0.006 & 0.006 \\
\hline $\mathrm{NaCl}$ & 0.04 & 0.015 & 0.04 & 0.007 \\
\hline Rhizoctonia & & $<0.001$ & $\ldots$ & $<0.001$ \\
\hline Cultivare & $n s^{f}$ & ns & $\mathrm{ns}$ & ns \\
\hline
\end{tabular}

a Treatments included $\left(\mathrm{NH}_{4}\right)_{2} \mathrm{SO}_{4}$ or $\mathrm{Ca}\left(\mathrm{NO}_{3}\right)_{2}$ at $10 \mathrm{mmol}$ of $\mathrm{N}$ and $\mathrm{NaCl}$ at $0.17 \mathrm{mmol}$; infested soil contained $0.2 \mathrm{~g}$ of millet colonized by $R$. solani.

${ }^{b}$ Plants grown in infested soils were rated for disease using a 1 to 5 scale: $1=$ no disease, $2=$ slight stunting, $3=$ stunting with slight wilt, $4=$ severe stunting and/or severe wilt, and $5=$ plant collapse, near death, or dead.

${ }^{c}$ Values in experiment I contained five replicates, and values in experiment II contained six replicates.

${ }^{\mathrm{d}}$ ANOVA $=$ analysis of variance. All interactions were not significant.

e Values from cvs. Detroit Dark Red and Early Wonder were combined.

${ }^{\mathrm{f}} \mathrm{ns}=$ not significant at $P>0.10$.
Another series of experiments was designed to examine the effect of different sources of $\mathrm{Cl}$ on growth and disease. Plants of both of the cultivars mentioned above were transplanted into sand in $10-\mathrm{cm}$ pots and treated with one of five $\mathrm{Cl}$ salt treatments. The base stock solution mentioned above was amended with $\left(\mathrm{NH}_{4}\right)_{2} \mathrm{SO}_{4}$ at 10 mmol and treated with $\mathrm{NaCl}, \mathrm{KCl}, \mathrm{CaCl}_{2}$, or $\mathrm{MgCl}_{2}$ at rates that yielded $0.17 \mathrm{mmol}$ of $\mathrm{Cl}$. A fifth treatment contained no $\mathrm{Cl}$ and served as a no $\mathrm{Cl}$ control. Therefore, 20 treatments (two cultivars by five $\mathrm{Cl}$ treatments by two inoculum treatments) were arranged randomly under the sodiumvapor lights on greenhouse benches. These experiments were repeated twice, with five and six replicates, respectively.

Greenhouse experiments were terminated after 6 to 8 weeks. Plants were rated for disease using a 1 to 5 scale: $1=$ no disease, $2=$ slight stunting, $3=$ stunting with slight wilt, $4=$ severe stunting and/or severe wilt, and 5 = plant collapse, near death, or dead. $R$. solani was reisolated by placing surface-disinfested pieces of diseased petioles on potato dextrose agar. Plants were cut at the soil line, and the fresh and dry weights were recorded. Roots and tops of beets grown in sand were washed in deionized water, oven-dried, and saved for tissue analyses, described below.

Field studies. A $100-\mathrm{m}^{2}$ section of a field that had been cropped to rye for 6 years was plowed during the spring of 1995. One-half of the field was treated with $100 \mathrm{~g}$ of the millet inoculum described above; the other half received sterile millet. Both sections were roto-tilled to

Table 2. Mineral composition of beet leaves treated with ammonium sulfate or calcium nitrate combined with or without $\mathrm{NaCl}$

\begin{tabular}{|c|c|c|c|c|c|c|c|c|c|c|c|c|c|}
\hline \multirow[b]{2}{*}{ Treatment $^{\mathrm{a}}$} & \multicolumn{3}{|c|}{$\mathrm{mmol} / \mathrm{g}$ tissue } & \multicolumn{10}{|c|}{$\mu \mathrm{mol} / \mathrm{g}$ tissue } \\
\hline & $\mathbf{N}$ & $\mathbf{P}$ & $\mathbf{K}$ & $\mathbf{C a}$ & Mg & $\mathrm{Na}$ & Cl & $\mathbf{S}$ & $\mathbf{F e}$ & Mn & $\mathbf{Z n}$ & $\mathrm{Cu}$ & B \\
\hline \multicolumn{14}{|l|}{$\begin{array}{l}\text { Leaves } \\
\end{array}$} \\
\hline $\left.\mathrm{NH}_{4}\right)_{2} \mathrm{SO}_{4}$ & $1.8^{\mathrm{b}}$ & 0.42 & 2.02 & 276 & 391 & 300 & 70 & 203 & 1.7 & 8.5 & 2.9 & 0.68 & 6.8 \\
\hline$\left(\mathrm{NH}_{4}\right)_{2} \mathrm{SO}_{4}+\mathrm{NaCl}$ & 1.7 & 0.40 & 1.46 & 232 & 323 & 1,815 & 250 & 156 & 1.7 & 13.1 & 2.6 & 0.82 & 6.4 \\
\hline $\mathrm{Ca}\left(\mathrm{NO}_{3}\right)_{2}$ & 1.6 & 0.34 & 2.17 & 259 & 362 & 321 & 100 & 147 & 1.0 & 6.9 & 2.4 & 0.68 & 5.4 \\
\hline $\mathrm{Ca}\left(\mathrm{NO}_{3}\right)_{2}+\mathrm{NaCl}$ & 1.4 & 0.31 & 1.60 & 244 & 325 & 2,169 & 2,888 & 112 & 1.5 & 9.2 & 2.6 & 0.65 & 5.8 \\
\hline \multicolumn{14}{|l|}{ Roots } \\
\hline$\left(\mathrm{NH}_{4}\right)_{2} \mathrm{SO}_{4}$ & 1.2 & 0.12 & 1.03 & 209 & 416 & 71 & 64 & 89 & 6.3 & 8.9 & 4.8 & 0.16 & 5.7 \\
\hline$\left(\mathrm{NH}_{4}\right)_{2} \mathrm{SO}_{4}+\mathrm{NaCl}$ & 1.3 & 0.11 & 0.63 & 196 & 420 & 538 & 393 & 62 & 8.2 & 13.4 & 5.0 & 0.19 & 4.7 \\
\hline $\mathrm{Ca}\left(\mathrm{NO}_{3}\right)_{2}$ & 1.3 & 0.11 & 0.91 & 223 & 463 & 82 & 67 & 84 & 7.1 & 5.7 & 3.9 & 0.13 & 4.4 \\
\hline $\mathrm{Ca}\left(\mathrm{NO}_{3}\right)_{2}+\mathrm{NaCl}$ & 1.5 & 0.11 & 0.70 & 202 & 439 & 624 & 368 & 56 & 11.8 & 5.3 & 3.5 & 0.15 & 4.3 \\
\hline \multicolumn{14}{|l|}{ ANOVA for leaves ${ }^{c}$} \\
\hline \multicolumn{14}{|l|}{ Source } \\
\hline $\mathrm{N}$ form & 0.001 & 0.01 & $\mathrm{~ns}^{\mathrm{d}}$ & ns & ns & $\mathrm{ns}$ & ns & 0.038 & & 0.032 & & & ns \\
\hline $\mathrm{NaCl}$ & 0.006 & $\mathrm{~ns}$ & 0.002 & ns & ns & 0.001 & 0.05 & ns & & 0.016 & & & ns \\
\hline Cultivare & $\mathrm{ns}$ & ns & $\mathrm{ns}$ & 0.047 & 0.001 & ns & $\mathrm{ns}$ & ns & & ns & & & 0.017 \\
\hline \multicolumn{14}{|l|}{ ANOVA for roots ${ }^{f}$} \\
\hline \multicolumn{14}{|l|}{ Source } \\
\hline $\mathrm{N}$ form & ns & 0.045 & ns & ns & ns & ns & ns & & & 0.005 & & & ns \\
\hline $\mathrm{NaCl}$ & ns & ns & 0.002 & ns & ns & 0.001 & 0.05 & & & 0.048 & & & ns \\
\hline Cultivare & 0.048 & $\mathrm{~ns}$ & $\mathrm{~ns}$ & 0.047 & 0.001 & ns & $\mathrm{ns}$ & & & ns & & & 0.017 \\
\hline
\end{tabular}

a Treatments included $\left(\mathrm{NH}_{4}\right)_{2} \mathrm{SO}_{4}$ or $\mathrm{Ca}\left(\mathrm{NO}_{3}\right)_{2}$ at $10 \mathrm{mmol}$ of $\mathrm{N}$ and $\mathrm{NaCl}$ at $0.17 \mathrm{mmol}$.

${ }^{\mathrm{b}}$ Values represent bulked samples from two separate experiments that contained five and six replicates, respectively.

c ANOVA $=$ analysis of variance. All interactions were not significant at $P=0.05$.

$\mathrm{d}$ ns $=$ not significant at $P>0.10$

e The values from cvs. Detroit Dark Red and Early Wonder were combined.

${ }^{\mathrm{f}}$ All interactions were not significant at $P=0.05$. 
a depth of $15 \mathrm{~cm}$. Rows $12.2 \mathrm{~m}$ long and spaced $0.6 \mathrm{~m}$ apart were seeded with $\mathrm{cv}$. Early Wonder seeds, with $2.5 \mathrm{~cm}$ between seedlings. After seedling emergence, rows were thinned to $7.5 \mathrm{~cm}$ spacing. All rows received a seasonal total of $112 \mathrm{~kg}$ of $\mathrm{N}$, $140 \mathrm{~kg}$ of $\mathrm{P}_{2} \mathrm{O}_{5}, 224 \mathrm{~kg}$ of $\mathrm{K}_{2} \mathrm{O}$, and $60 \mathrm{Kg}$ of $\mathrm{CaSO}_{4}$ per ha.

Sections of row $1 \mathrm{~m}$ long that had uniform seedling emergence were selected as plots $\left(0.6 \mathrm{~m}^{2}\right)$. The treatments included $\left(\mathrm{NH}_{4}\right)_{2} \mathrm{SO}_{4}$ or $\mathrm{Ca}\left(\mathrm{NO}_{3}\right)_{2}$ applied at equal rates of $\mathrm{N}$, and $\mathrm{NaCl}$ was applied at 560 $\mathrm{kg} / \mathrm{ha}$, with an equal number of untreated rows serving as controls. Thus, eight treatments (two $\mathrm{N}$ forms by two $\mathrm{NaCl}$ treatment by two inoculum treatments) were arranged in a split-plot design, with inoculum treatment as the major plot and $\mathrm{N}$ form and $\mathrm{NaCl}$ treatments as the subplots; there were four replicate plots.

At the time the beet seedlings were thinned, $70 \%$ of the total fertilizers, including the $\mathrm{N}$ forms and $\mathrm{NaCl}$ treatments, was banded along side the row. The remaining 30\% was applied 4 weeks later. Two months after planting, a fully expanded leaf from each plant in each replicate plot was sampled, bulked, and allowed to air-dry. Plants were rated using the scale described above. The number of marketable beets with their tops were harvested and weighed. Beets less than $3 \mathrm{~cm}$ in diameter were not weighed, but these were rare. Most beets had diameters greater than $6 \mathrm{~cm}$. The experiment was repeated by establishing the same design 3 weeks later in a plot adjacent to the first design.

The second experiment differed from the first in that seedlings were germinated first in the greenhouse in potting soil and transplanted at $7.5 \mathrm{~cm}$ spacing and treated with the fertilizer. This was done to insure a uniform stand of seedlings at the time fertilizers were applied. The second experiment also did not include plants grown in noninfested soil.

Tissue analyses. Dried leaf and root tissues from healthy plants were ground to powder in a mortar with a pestle. Total $\mathrm{N}$ was determined by digesting $0.25 \mathrm{~g}$ of tissue in $\mathrm{H}_{2} \mathrm{SO}_{4}$ and was colorimetrically analyzed by the Nestler reaction. P, K, $\mathrm{Na}, \mathrm{Ca}, \mathrm{Mg}, \mathrm{S}, \mathrm{Fe}, \mathrm{Mn}, \mathrm{Zn}, \mathrm{Cu}$, and $\mathrm{B}$ were analyzed by microwaving $0.5 \mathrm{~g}$ of tissue in $\mathrm{HCl}$ and $\mathrm{HNO}_{3}$ in a CEM MDS 81D microwave (CEM Co., Matthews, NC) and using inductively coupled plasma-emission (ICP) spectroscopy on an ARL 3520 ICP-OES spectrophotometer (Fison Instruments, Deerborn, MI). Free chlorides were detected by agitating $0.2 \mathrm{~g}$ of tissue in $20 \mathrm{ml}$ of deionized water and injecting a diluted and filtered sample into a Dionex 2010i ion detector (Dionex Corp. Sunnyvale, CA). Mineral concentrations of $\mathrm{N}, \mathrm{P}$, and $\mathrm{K}$ are expressed as millimoles per gram of tissue, and all remaining elements are expressed as micromoles per gram of tissue.
Statistics. A factorial analysis of variance was used in greenhouse studies to detect treatment interactions on dry weights and nutrient concentrations. Disease ratings were analyzed by the Kruskal-Wallis rank test. Orthogonal contrasts were employed to test post-hoc comparisons. Field studies were analyzed by a split-plot analysis of variance.

\section{RESULTS}

Effect of $\mathbf{N}$ form and $\mathrm{NaCl}$ on growth, disease, and mineral composition. The inoculum density of $0.2 \mathrm{~g}$ of colonized millet inoculum per liter of soil produced significant reductions in the dry weights of both cultivars compared to healthy controls (Table 1). Cv. Early Wonder appeared to be slightly more tolerant than Detroit Dark Red, but the cultivars did not significantly differ in dry weights, so their values were averaged. No significant interactions between $\mathrm{N}$ form and $\mathrm{NaCl}$ were detected. Plants grown in noninfested and infested soil were 17 and $32 \%$ larger, respectively, when treated with $\mathrm{Ca}\left(\mathrm{NO}_{3}\right)_{2}$ than when treated with $\left(\mathrm{NH}_{4}\right)_{2} \mathrm{SO}_{4}$. $\mathrm{NaCl}$ also increased dry weight by $40 \%$ in noninfested soil and by $12 \%$ in infested soil compared to no $\mathrm{NaCl}$.

Table 3. The influence of different chloride salts on beets grown in noninfested soil or soil infested with Rhizoctonia solani (anastomosis group 2-2)

\begin{tabular}{|c|c|c|c|c|c|}
\hline \multirow[b]{2}{*}{ Chloride salt $^{\mathbf{a}}$} & \multicolumn{2}{|c|}{ Experiment I } & \multicolumn{3}{|c|}{ Experiment II } \\
\hline & $\begin{array}{l}\text { Disease } \\
\text { ratingb }\end{array}$ & $\begin{array}{c}\text { Dry } \\
\text { weight (g) }\end{array}$ & $\begin{array}{c}\text { Disease } \\
\text { rating }\end{array}$ & $\begin{array}{c}\text { Fresh } \\
\text { weight }(g)\end{array}$ & $\begin{array}{c}\text { Dry } \\
\text { weight (g) }\end{array}$ \\
\hline \multicolumn{6}{|l|}{ Noninfested soil } \\
\hline $\mathrm{No} C l$ & $\ldots$ & $1.14^{\mathrm{c}}$ & $\ldots$ & 12.1 & 1.49 \\
\hline $\mathrm{NaCl}$ & $\ldots$ & 1.30 & $\ldots$ & 16.4 & 1.53 \\
\hline $\mathrm{KCl}$ & $\ldots$ & 1.34 & $\ldots$ & 15.8 & 1.60 \\
\hline $\mathrm{CaCl}_{2}$ & $\ldots$ & 1.43 & $\ldots$ & 14.7 & 1.48 \\
\hline $\mathrm{MgCl}_{2}$ & $\cdots$ & 1.50 & $\cdots$ & 15.7 & 1.64 \\
\hline \multicolumn{6}{|l|}{ Infested soil } \\
\hline No $\mathrm{Cl}$ & 3.4 & 1.12 & 2.9 & 9.0 & 1.00 \\
\hline $\mathrm{NaCl}$ & 2.1 & 1.27 & 1.8 & 15.2 & 1.34 \\
\hline $\mathrm{KCl}$ & 2.0 & 1.08 & 2.0 & 13.5 & 1.31 \\
\hline $\mathrm{CaCl}_{2}$ & 2.4 & 1.18 & 2.2 & 14.7 & 1.48 \\
\hline $\mathrm{MgCl}_{2}$ & 2.1 & 1.32 & 2.3 & 11.3 & 1.21 \\
\hline \multicolumn{6}{|l|}{ ANOVA $^{\mathrm{d}}$} \\
\hline \multicolumn{6}{|l|}{ Source $(P)$} \\
\hline $\mathrm{Cl}$ salt & 0.04 & 0.015 & 0.04 & $<0.001$ & $\mathrm{~ns}$ \\
\hline Rhizoctonia & & 0.010 & $\ldots$ & 0.003 & 0.006 \\
\hline Cultivar $^{\mathrm{e}}$ & $n s^{f}$ & ns & $\ldots$ & $\ldots$ & $\ldots$ \\
\hline \multicolumn{6}{|l|}{ Orthogonal contrasts $(P)$} \\
\hline $\mathrm{NaCl}$ vs. control & $\ldots$ & 0.059 & $\ldots$ & $\ldots$ & 0.001 \\
\hline $\mathrm{KCl}$ vs. control & $\ldots$ & ns & $\ldots$ & $\ldots$ & 0.001 \\
\hline $\mathrm{CaCl}_{2}$ vs. control & $\ldots$ & 0.036 & $\ldots$ & $\ldots$ & 0.001 \\
\hline $\mathrm{MgCl}_{2}$ vs. control & $\ldots$ & 0.001 & $\ldots$ & $\ldots$ & 0.012 \\
\hline $\mathrm{NaCl}$ vs. other salts & $\ldots$ & ns & $\ldots$ & $\ldots$ & ns \\
\hline $\mathrm{KCl}$ vs. $\mathrm{NaCl}$ & $\ldots$ & ns & $\ldots$ & $\ldots$ & $\mathrm{ns}$ \\
\hline $\mathrm{CaCl}_{2}$ vs. $\mathrm{NaCl}$ & $\ldots$ & ns & $\ldots$ & $\ldots$ & ns \\
\hline $\mathrm{MgCl}_{2}$ vs. $\mathrm{NaCl}$ & $\ldots$ & ns & $\ldots$ & $\ldots$ & ns \\
\hline
\end{tabular}

a Treatments included $\mathrm{Cl}$ salt $(0.17 \mathrm{mmol}$ of $\mathrm{Cl})$; infested soil contained $0.2 \mathrm{~g}$ of millet colonized by R. solani.

${ }^{\mathrm{b}}$ Plants were rated for disease using a 1 to 5 scale: $1=$ no disease, $2=$ slight stunting, $3=$ stunting with slight wilt, $4=$ severe stunting and/or severe wilt, and $5=$ plant collapse, near death, or dead

${ }^{c}$ Values in both experiments contained five replicates.

${ }^{d}$ ANOVA $=$ analysis of variance. All interactions were not significant.

e The values from cvs. Detroit Dark Red and Early Wonder were combined.

${ }^{\mathrm{f}} \mathrm{ns}=$ not significant at $P>0.10$.
Overall, Early Wonder had less $\mathrm{Ca}, \mathrm{Mg}$,
and $\mathrm{B}$ in leaves and less $\mathrm{N}, \mathrm{Ca}, \mathrm{Mg}$, and $\mathrm{B}$ in roots than Detroit Dark Red, but none of the other elements differed between the cultivars (data not shown). Therefore, the . Roots contained lower levels of minerdid leaves, with the exception of teraction occurred between the cultivars, $\mathrm{N}$ form, or $\mathrm{NaCl}$. Beets treated with $\left(\mathrm{NH}_{4}\right)_{2} \mathrm{SO}_{4}$ had more $\mathrm{N}, \mathrm{P}, \mathrm{S}$, and $\mathrm{Mn}$ than plants with $\mathrm{Ca}\left(\mathrm{NO}_{3}\right)_{2}$. Compared to con$\mathrm{N}, \mathrm{Na}, \mathrm{Cl}$, and $\mathrm{Mn}$ and decreased $\mathrm{K}$. The treatments affected the mineral concentrations in roots similar to the effect on concentrations in the leaves, in that no interacoccuin effect treatments with $\mathrm{Ca}\left(\mathrm{NO}_{3}\right)_{2}$, roots treated with $\left(\mathrm{NH}_{4}\right)_{2} \mathrm{SO}_{4}$ had more $\mathrm{P}$ and $\mathrm{Mn}$. Adding $\mathrm{NaCl}$ under both $\mathrm{N}$ forms increased $\mathrm{Na}, \mathrm{Cl}$, and $\mathrm{Mn}$ and decreased $\mathrm{K}$ levels compared to no $\mathrm{NaCl}$.

Effect of different chloride salts on growth, disease, and mineral composiweight of beet plants. The effect was clearly dependent on the presence or absence of $\mathrm{Cl}$ rather than on any $\mathrm{Cl}$ source, because neither values were averaged across cultivars (Table

\footnotetext{
as micromoles per gram of tissue.
}

\footnotetext{
ins $=$ not significant at $P>0.10$
} 
Table 4. Mineral composition of beet roots treated with different chloride salts (experiment I)

\begin{tabular}{|c|c|c|c|c|c|c|c|c|c|c|c|c|c|}
\hline \multirow[b]{2}{*}{ Treatment $^{\mathrm{a}}$} & \multicolumn{3}{|c|}{ mmol/g tissue } & \multicolumn{10}{|c|}{$\mu \mathrm{mol} / \mathrm{g}$ tissue } \\
\hline & $\mathbf{N}$ & $\mathbf{P}$ & $\mathbf{K}$ & $\mathbf{C a}$ & Mg & $\mathbf{N a}$ & $\mathbf{C l}$ & $\mathbf{S}$ & $\mathbf{F e}$ & Mn & $\mathbf{Z n}$ & $\mathbf{C u}$ & B \\
\hline $\mathrm{No} C l$ & $1.2^{\mathrm{b}}$ & 0.42 & 1.52 & 278 & 392 & 250 & 70 & 203 & 1.7 & 8.5 & 2.9 & 0.08 & 6.7 \\
\hline $\mathrm{NaCl}$ & 1.3 & 0.36 & 1.43 & 379 & 508 & 1,431 & 163 & 259 & 1.6 & 18.0 & 3.5 & 0.11 & 6.0 \\
\hline $\mathrm{KCl}$ & 0.9 & 0.27 & 2.60 & 246 & 587 & 577 & 156 & 167 & 1.4 & 13.1 & 2.6 & 0.10 & 5.3 \\
\hline $\mathrm{CaCl}_{2}$ & 1.3 & 0.25 & 1.12 & 795 & 469 & 559 & 150 & 192 & 1.6 & 17.4 & 4.1 & 0.12 & 6.5 \\
\hline $\mathrm{MgCl}_{2}$ & 1.4 & 0.28 & 1.07 & 347 & 1,058 & 486 & 143 & 159 & 1.4 & 16.0 & 2.9 & 0.10 & 6.1 \\
\hline \multicolumn{14}{|l|}{$\operatorname{ANOVA}(P)^{\mathrm{c}}$} \\
\hline \multicolumn{14}{|l|}{ Source } \\
\hline Chloride source & & 0.013 & 0.015 & 0.001 & 0.087 & 0.091 & 0.002 & & & 0.005 & & & \\
\hline Cultivar $^{\mathrm{d}}$ & & $\mathrm{ns}^{\mathrm{e}}$ & ns & ns & ns & ns & ns & & & ns & & & \\
\hline \multicolumn{14}{|l|}{ Orthogonal contrasts } \\
\hline $\mathrm{NaCl}$ vs. control & & $\mathrm{ns}$ & ns & 0.077 & ns & 0.001 & 0.001 & & & 0.001 & & & \\
\hline $\mathrm{KCl}$ vs. control & & 0.007 & 0.004 & ns & ns & ns & 0.001 & & & 0.022 & & & \\
\hline $\mathrm{CaCl}_{2}$ vs. control & & 0.003 & ns & 0.001 & ns & ns & 0.001 & & & 0.003 & & & \\
\hline $\mathrm{MgCl}_{2}$ vs. control & & 0.007 & ns & ns & 0.049 & ns & 0.001 & & & 0.003 & & & \\
\hline $\mathrm{NaCl}$ vs. other salts & & 0.015 & 0.022 & ns & ns & ns & ns & & & 0.083 & & & \\
\hline $\mathrm{KCl}$ vs. $\mathrm{NaCl}$ & & 0.047 & 0.003 & 0.035 & ns & ns & ns & & & ns & & & \\
\hline $\mathrm{CaCl}_{2}$ vs. $\mathrm{NaCl}$ & & 0.015 & ns & 0.001 & ns & ns & ns & & & ns & & & \\
\hline $\mathrm{MgCl}_{2}$ vs. $\mathrm{NaCl}$ & & 0.047 & ns & ns & 0.086 & ns & ns & & & ns & & & \\
\hline
\end{tabular}

a Treatments included $\mathrm{Cl}$ salt $(0.17 \mathrm{mmol}$ of $\mathrm{Cl})$; infested soil contained $0.2 \mathrm{~g}$ of millet colonized by $R$. solani.

b Values in both experiments contained five replicates.

c ANOVA = analysis of variance.

$\mathrm{d}$ The values from cvs. Detroit Dark Red and Early Wonder were combined.

e ns $=$ not significant at $P>0.10$.

Table 5. Root yield of table beets treated with ammonium sulfate or calcium nitrate with or without $\mathrm{NaCl}$ and grown in noninfested soil or soil infested with Rhizoctonia solani (anastomosis group 2-2)

\begin{tabular}{|c|c|c|c|c|}
\hline \multirow[b]{2}{*}{ Treatment $^{\mathrm{a}}$} & \multicolumn{2}{|c|}{ Experiment I } & \multicolumn{2}{|c|}{ Experiment II } \\
\hline & $\begin{array}{l}\text { Disease } \\
\text { rating }^{b}\end{array}$ & $\begin{array}{c}\text { Yield } \\
(\mathrm{kg} / \mathrm{m} \text { row })\end{array}$ & $\begin{array}{c}\text { Disease } \\
\text { rating }\end{array}$ & $\begin{array}{c}\text { Yield } \\
(\mathrm{kg} / \mathrm{m} \text { row })\end{array}$ \\
\hline \multicolumn{5}{|l|}{ Noninfested soil } \\
\hline$\left(\mathrm{NH}_{4}\right)_{2} \mathrm{SO}_{4}$ & 1.2 & $2.25^{\mathrm{c}}$ & $\ldots^{\mathrm{d}}$ & $\ldots$ \\
\hline$\left(\mathrm{NH}_{4}\right)_{2} \mathrm{SO}_{4}+\mathrm{NaCl}$ & 1.0 & 2.35 & $\ldots$ & $\ldots$ \\
\hline $\mathrm{Ca}\left(\mathrm{NO}_{3}\right)_{2}$ & 1.0 & 2.06 & $\ldots$ & $\ldots$ \\
\hline $\mathrm{Ca}\left(\mathrm{NO}_{3}\right)_{2}+\mathrm{NaCl}$ & 1.0 & 2.15 & $\ldots$ & $\ldots$ \\
\hline \multicolumn{5}{|l|}{ Infested soil } \\
\hline$\left(\mathrm{NH}_{4}\right)_{2} \mathrm{SO}_{4}$ & 3.1 & 0.60 & 3.8 & 0.53 \\
\hline$\left(\mathrm{NH}_{4}\right)_{2} \mathrm{SO}_{4}+\mathrm{NaCl}$ & 2.8 & 0.81 & 2.7 & 1.00 \\
\hline $\mathrm{Ca}\left(\mathrm{NO}_{3}\right)_{2}$ & 1.5 & 0.98 & 2.0 & 0.87 \\
\hline $\mathrm{Ca}\left(\mathrm{NO}_{3}\right)_{2}+\mathrm{NaCl}$ & 1.7 & 0.95 & 2.5 & 0.97 \\
\hline \multicolumn{5}{|l|}{$\operatorname{ANOVA}(P)^{\mathrm{e}}$} \\
\hline \multicolumn{5}{|l|}{ Source } \\
\hline $\mathrm{N}$ form & 0.04 & $n s^{f}$ & 0.06 & ns \\
\hline $\mathrm{NaCl}$ & $\mathrm{ns}$ & ns & ns & ns \\
\hline $\mathrm{N}$ form $\times \mathrm{NaCl}$ & $\ldots$ & 0.086 & $\ldots$ & 0.050 \\
\hline Rhizoctonia & $\ldots$ & $<0.001$ & $\ldots$ & $\ldots$ \\
\hline $\mathrm{N}$ form $\times \mathrm{NaCl} \times$ & & & & \\
\hline Rhizoctonia & $\ldots$ & 0.093 & $\ldots$ & $\ldots$ \\
\hline
\end{tabular}

a Treatments included $\left(\mathrm{NH}_{4}\right)_{2} \mathrm{SO}_{4}$ or $\mathrm{Ca}\left(\mathrm{NO}_{3}\right)_{2}$ at $112 \mathrm{~kg}$ of $\mathrm{N}$ per ha and $\mathrm{NaCl}$ at $560 \mathrm{~kg} / \mathrm{ha}$; infested soil contained $0.2 \mathrm{~g}$ of millet colonized by $R$. solani.

b Plants were rated for disease using a 1 to 5 scale: $1=$ no disease, $2=$ slight stunting, $3=$ stunting with slight wilt, 4 = severe stunting and/or severe wilt, and 5 = plant collapse, near death, or dead.

${ }^{c}$ Values in both experiments contained four replicates.

d Plants in noninfested soil were not harvested.

e $\mathrm{ANOVA}=$ analysis of variance.

${ }^{\mathrm{f}} \mathrm{ns}=$ not significant at $P>0.10$.

salt was superior or inferior to $\mathrm{NaCl}$ (Table 3). In the experimental repetition, the $\mathrm{Cl}$ salt treatments had similar effects, except that dry weights were not significantly different from controls, but the fresh plant weights increased. Once again, the source of the $\mathrm{Cl}$ did not affect plant weight.

The mineral composition of these plants was affected accordingly, in that the ac- root and crown root (Table 5). However, in infested soils, there was an interaction between $\left(\mathrm{NH}_{4}\right)_{2} \mathrm{SO}_{4}$ and $\mathrm{NaCl}$ that increased yields more than when $\mathrm{NaCl}$ was absent and more than when $\mathrm{NaCl}$ was combined with $\mathrm{Ca}\left(\mathrm{NO}_{3}\right)_{2}$. When the experiment was repeated in infested soils, the same interaction was observed. Mineral analyses of the sampled leaves at harvest revealed that treatment with $\left(\mathrm{NH}_{4}\right)_{2} \mathrm{SO}_{4}$ tended to increase $\mathrm{Mn}$ but decreased $\mathrm{K}$ (Table 6). $\mathrm{NaCl}$ increased $\mathrm{Na}$ and $\mathrm{Cl}$ in leaves, whereas $\mathrm{Mn}$ was only slightly increased compared to no $\mathrm{NaCl}$.

\section{DISCUSSION}

In both greenhouse and field experiments, the yield of table beets increased with use of $\mathrm{Ca}\left(\mathrm{NO}_{3}\right)_{2}$ more than with $\left(\mathrm{NH}_{4}\right)_{2} \mathrm{SO}_{4}$, and the differences in yield tended to be greater in the presence of $R$. solani than in noninfested soils. Sodium chloride also had a growth-enhancing effect that tended to be greater under the $\left(\mathrm{NH}_{4}\right)_{2} \mathrm{SO}_{4}$ regime than under the $\mathrm{Ca}\left(\mathrm{NO}_{3}\right)_{2}$ regime. In both field studies, the inclusion of $\mathrm{NaCl}$ with $\left(\mathrm{NH}_{4}\right)_{2} \mathrm{SO}_{4}$ increased yield by 26 and $41 \%$, respectively, but only was marginal when $\mathrm{NaCl}$ was combined with $\mathrm{Ca}\left(\mathrm{NO}_{3}\right)_{2}$

The current study supports past reports that seedling diseases caused by $R$. solani are less severe with $\mathrm{NO}_{3}-\mathrm{N}$ than with $\mathrm{NH}_{4}$ $\mathrm{N}$ nutrition (19). In general, $\mathrm{NH}_{4}-\mathrm{N}$ nutrition is more harmful to young seedlings than is $\mathrm{NO}_{3}-\mathrm{N}$, because small plants lack the available carbohydrates to convert the toxic $\mathrm{NH}_{4}{ }^{+}$into amino acids (26). However, Rush and Winter (27) observed that the incidence of Rhizoctonia crown and root rot of sugar beet was greater after rotation crops that left high levels of resi- 
Table 6. Mineral composition of field-grown beet leaves treated with ammonium sulfate or calcium nitrate combined with or without NaCl

\begin{tabular}{|c|c|c|c|c|c|c|c|c|c|c|c|c|c|}
\hline \multirow[b]{2}{*}{ Treatment $^{\mathrm{a}}$} & \multicolumn{3}{|c|}{$\mathrm{mmol} / \mathrm{g}$ tissue } & \multicolumn{10}{|c|}{$\mu \mathrm{mol} / \mathrm{g}$ tissue } \\
\hline & $\mathbf{N}$ & $\mathbf{P}$ & $\mathbf{K}$ & $\mathbf{C a}$ & Mg & $\mathbf{N a}$ & Cl & $\mathbf{S}$ & $\mathbf{F e}$ & Mn & $\mathbf{Z n}$ & $\mathrm{Cu}$ & $\mathbf{B}$ \\
\hline$\left(\mathrm{NH}_{4}\right)_{2} \mathrm{SO}_{4}$ & $2.8^{\mathrm{b}}$ & 0.12 & 1.99 & 356 & 917 & 326 & 87 & 170 & 4.4 & 1.3 & 0.6 & 0.14 & 4.7 \\
\hline$\left(\mathrm{NH}_{4}\right)_{2} \mathrm{SO}_{4}+\mathrm{NaCl}$ & 2.7 & 0.13 & 1.95 & 385 & 971 & 429 & 159 & 203 & 4.8 & 1.9 & 0.7 & 0.20 & 4.8 \\
\hline $\mathrm{Ca}\left(\mathrm{NO}_{3}\right)_{2}$ & 2.7 & 0.11 & 1.67 & 386 & 969 & 848 & 67 & 166 & 6.9 & 1.1 & 0.6 & 0.17 & 4.9 \\
\hline $\mathrm{Ca}\left(\mathrm{NO}_{3}\right)_{2}+\mathrm{NaCl}$ & 2.7 & 0.15 & 1.73 & 414 & 912 & 653 & 196 & 225 & 5.4 & 1.3 & 0.7 & 0.23 & 6.2 \\
\hline \multicolumn{14}{|l|}{$\operatorname{ANOVA}(P)^{\mathrm{c}}$} \\
\hline \multicolumn{14}{|l|}{ Source } \\
\hline $\mathrm{N}$ form & & & 0.013 & & & 0.004 & $\mathrm{~ns}^{\mathrm{d}}$ & & & 0.09 & & & \\
\hline $\mathrm{NaCl}$ & & & ns & & & 0.050 & 0.002 & & & 0.08 & & & \\
\hline
\end{tabular}

a Treatments included $\left(\mathrm{NH}_{4}\right)_{2} \mathrm{SO}_{4}$ or $\mathrm{Ca}\left(\mathrm{NO}_{3}\right)_{2}$ at $112 \mathrm{~kg}$ of $\mathrm{N}$ per ha and $\mathrm{NaCl}$ at $560 \mathrm{~kg} / \mathrm{ha}$.

b Values represent bulked samples from two blocks in each experiment.

c ANOVA = analysis of variance. All interactions were not significant at $P<0.10$.

${ }^{\mathrm{d}} \mathrm{ns}=$ not significant at $P>0.10$.

dual soil $\mathrm{NO}_{3}-\mathrm{N}$ compared to crops that left low $\mathrm{NO}_{3}-\mathrm{N}$ levels. Late-season nitrate reduced sugar production in sugar beet roots and favored disease $(21,34)$. It is difficult to compare these observations to the current one because $\mathrm{NH}_{4}-\mathrm{N}$ was not compared to $\mathrm{NO}_{3}-\mathrm{N}$. Also, late-season $\mathrm{NO}_{3}-\mathrm{N}$ levels may not be of great concern to table beet growers, because sugar production is less important than for sugar beets.

$\mathrm{NaCl}$ was beneficial to beet growth and suppressed Rhizoctonia root and crown rot. The original studies on $\mathrm{NaCl}$ use with sugar beets concentrated on the ability of $\mathrm{Na}$ to replace $K$ in metabolic functions (13, 23). The current study also showed that applications of $\mathrm{NaCl}$ resulted in a decrease in $\mathrm{K}$ leaf concentrations, possibly due to replacement. The phenomenon of $\mathrm{Na} / \mathrm{K}$ replacement may be specific to B. vulgaris, because $\mathrm{K}$ replacement is not observed with other saline-tolerant plants, such as celery and asparagus $(9,29)$. However, there was insufficient evidence to consider $\mathrm{Na}$ as a major ion in disease suppression, because greenhouse trials found that $\mathrm{NaCl}$ was not superior to $\mathrm{CaCl}_{2}, \mathrm{KCl}$, or $\mathrm{MgCl}_{2}$ in suppressing disease. Past studies on sugar beets touted the value of $\mathrm{Na}$ in growth and water relations and ignored the contributions of $\mathrm{Cl}(3,6,13)$. On wheat, yellow rust caused by Puccinia striiformis was less severe when $\mathrm{NaCl}$ was combined with $\mathrm{NaNO}_{3}$ than when $\mathrm{NaNO}_{3}$ was applied alone (28), implicating $\mathrm{Cl}$ as the determining ion in disease suppression. An interesting area for future work would be to determine the role of different $\mathrm{Na}$ and $\mathrm{Cl}$ sources in Rhizoctonia diseases of beets in K-deficient soils.

Unlike $\mathrm{Na}, \mathrm{Cl}$ has received much attention as an element that enhances growth and suppresses disease $(14,22)$. $\mathrm{Cl}$ concentrations increased 6- and 25-fold for leaves and roots, respectively, and reached levels comparable to $\mathrm{K}$ and $\mathrm{Ca}$, a phenomenon not uncommon in many plants $(9,14,16$, 29,35). There are many possible mechanisms, not mutually exclusive, that may explain the disease-suppressive effects of $\mathrm{Cl}$ and influence host resistance.

$\mathrm{Cl}$ inhibits soil nitrification and tends to keep soil $\mathrm{N}$ in $\mathrm{NH}_{4}-\mathrm{N}$ form, which can affect microbial populations in the rhizosphere and trace-element availability (18). In fact, $\mathrm{Cl}$ applications have been used to enhance sugar beet quality by reducing the availability of residual $\mathrm{NO}_{3}-\mathrm{N}$ levels (21, 24). Chloride also lowers plant water potential, which may increase the ability of the plant to maintain turgor when water absorption by roots has been compromised by pathogens $(5,9)$. Another possible mechanism could be a reduction in the amount of organic acids released as exudates from roots that are fed $\mathrm{Cl}(8,30)$. These alterations in exudates could deprive root pathogens of the substrates they need prior to pathogenesis. $\mathrm{Cl}$ applications also increase the availability of $\mathrm{Mn}(10,12,14,16,20)$, and there is convincing evidence in the current study showing that Mn levels and disease suppression are increased when $\mathrm{Cl}$ is applied. The greenhouse studies with different $\mathrm{Cl}$ salts found that, along with increased plant weights and $\mathrm{Cl}$ levels, the concentrations of Mn were increased.

In the combination studies with $\mathrm{N}$ form/ $\mathrm{Cl}$, the largest increase in $\mathrm{Mn}$ was found when $\mathrm{NaCl}$ was combined with $\left(\mathrm{NH}_{4}\right)_{2} \mathrm{SO}_{4}$, and this combination frequently resulted in the greatest increase in growth in greenhouse studies and the largest increase in yield in the field compared to $\left(\mathrm{NH}_{4}\right)_{2} \mathrm{SO}_{4}$ alone. The inclusion of $\mathrm{NaCl}$ with $\mathrm{Ca}\left(\mathrm{NO}_{3}\right)_{2}$ was less beneficial to growth, yield, and $\mathrm{Mn}$ levels. This may because $\mathrm{NO}_{3}-\mathrm{N}$ and $\mathrm{Cl}$ ions compete for absorption sites on plant roots (14). The disease-suppressive effects of $\mathrm{Ca}\left(\mathrm{NO}_{3}\right)_{2}$ compared to $\left(\mathrm{NH}_{4}\right)_{2} \mathrm{SO}_{4}$ may operate by mechanisms other than those associated with increased Mn availability, such as increasing $\mathrm{Ca}$ levels in cell walls.

Much attention has been given to the effect that $\mathrm{Cl}$ has on $\mathrm{Mn}$ availability, because $\mathrm{Mn}$ also has been implicated in disease suppression $(10-12,14,20,31)$. $\mathrm{Cl}$ can chemically reduce $\mathrm{Mn}$ oxides in soil (32), and evidence for asparagus has shown that Mnreducing bacteria are associated more with asparagus roots treated with $\mathrm{NaCl}$ than with nontreated roots (10). Manganese is an activator for enzymes that function in phenol metabolism (20). A current hypothesis holds that root cells containing ample Mn may be able to produce antifungal barriers, such as lignin, faster than cells containing lower levels of Mn (20).

The response of other table beet diseases to $\mathrm{Cl}$ salts is unknown. High salt levels in soil may aggravate other beet diseases, such as Pythium root rot caused by Pythium ultimum. Nevertheless, the use of $\mathrm{Cl}$ salts should receive further consideration in the management of Rhizoctonia root and crown rot of table beets.

\section{ACKNOWLEDGMENT}

I thank E. O'Dowd and E. Keller for technical assistance.

\section{LITERATURE CITED}

1. Abawi, G. S., Crosier, D. C., Cobb, A. C., and Becker, R. F. 1986. Root rot of table beets in New York State. N.Y. Food Life Sci. Bull 115

2. Abawi, G. S., Olaya, G., and Ludwig, J. W. 1995. Occurrence of Thanatephorus cucumer is on snap bean in New York. (Abstr.) Phytopathology $85: 1554$

3. Adams, S. 1961. The effect of sodium of potassium fertiliser on the mineral composition of sugar beet. J. Agric Sci. Cambridge 56: 383-388.

4. Afanasiev, M. M., and Carlson, W. E. 1942 The relation of phosphorous and nitrogen ratio to the amount of seedling diseases of sugar beets. Ann. Am. Soc. Sugar Beet Techn. 11:1-5.

5. Christensen, N. W., Taylor, R. G., Jackson, T. L., and Mitchell, B. L. 1981. Chloride effects on water potentials and yields of winter wheat infected with take-all root rot. Agron. J. 73:1093-1098.

6. Durrant, M. J., Draycott, A. P., and Milford, G. F. J. 1977. Effect of sodium fertiliser on water status and yield of sugar beet. Ann. Appl. Biol. 88:321-328.

7. Elmer, W. H. 1989. Effects of chloride and nitrogen form on asparagus growth and on infection by Fusarium. Plant Dis. 73:736-740.

8. Elmer, W. H. 1990. Effect of $\mathrm{NaCl}$ on carbohydrates and malate production in asparagus roots and on infection by Fusarium. (Abstr.) Phytopathology 80:1025.

9. Elmer, W. H. 1992. Suppression of Fusarium crown and root rot of asparagus with sodium chloride. Phytopathology 82:97-104.

10. Elmer, W. H. 1995. The association among Mnreducing bacteria and sodium chloride applications in the suppression of Fusarium crown and root rot of asparagus. Phytopathology 85: 1461-1467.

11. Elmer, W. H., and Ferrandino, F. J. 1994. Comparison of ammonium sulfate and calcium ni- 
trate fertilization effects on Verticillium wilt of eggplant. Plant Dis. 78:811-816.

12. Elmer, W. H., and LaMondia, J. A. 1995. Influence of mineral nutrition on strawberry black root rot. Adv. Strawberry Res. 14:42-48.

13. El-Sheikh, A. M., Ulrich, A., and Broyer, T. C. 1967. Sodium and rubidium as possible nutrients for sugar beet plants. Plant Physiol. 42: 1202-1208.

14. Fixen, P. E. 1993. Crop response to chloride. Adv. Agron. 50:107-150.

15. Hammer, P. M., and Beene, E. J. 1941. Effects of applying common salt to a muck soil on yield composition and quality of certain vegetable crops and on the composition of the soil producing them. Agron. J. 33:952-979.

16. Heckman, J. R. 1995. Corn response to chloride in maximum yield research. Agron. J. 87: 415-419.

17. Hoagland, D. R., and Arnon, D. I. 1938. The water culture method for growing plants without soil. Calif. Agric. Exp. Stn. Circ. 347.

18. Huber, D. M. 1989. The role of nutrition in the take-all disease of wheat and other small grains. Pages 46-74 in: Soilborne Plant Pathogens: Management of Diseases with Macroand Microelements. A. Englehard, ed. The American Phytopathological Society, St. Paul, MN.

19. Huber, D. M., and Watson, R. D. 1974. Nitrogen form and plant disease. Annu. Rev. Phytopathol. 12:139-165.
20. Huber, D. M., and Wilhelm, N. S. 1988. The role of manganese in resistance to plant disease. Pages 155-173 in: Manganese in Soils and Plants. R. D. Graham, R. J. Hannam, and N. C. Uren, eds. Kluwer Academic Publishers, Dordrecht, Netherlands.

21. Ludwick, A. E., Gilbert, W. A., and Westfall, D. G. 1980. Sugarbeet quality as related to $\mathrm{KCl}$ fertilization. Agron. J. 72:453-456.

22. Maas, E. V. 1986. Physiological response of plants to chloride. Pages 4-20 in: Chloride and Crop Production. T. L. Jackson, ed. Potash and Phosphate Institute, Atlanta.

23. Marschner, H., and Possingham, J. V. 1975. Effect of $\mathrm{K}^{+}$and $\mathrm{Na}^{+}$on growth of leaf discs of sugar beet and spinach. Z. Pflanzenhiol. 75: 6-16.

24. Moraghan, J. T. 1987. Nitrogen fertilizer effects on uptake and partitioning of chloride in sugarbeet plants. Agron. J. 79:1054-1057.

25. Olaya, G., and Abawi, G. S. 1994. Characteristics of Rhizoctonia solani and binucleate Rhizoctonia species causing foliar blight and root rot on table beets in New York State. Plant Dis. 78:800-804.

26. Pate, J. S. 1973. Uptake, assimilation and transport of nitrogen compounds by plants. Soil Biol. Biochem. 5:109-119.

27. Rush, C. M., and Winter, S. R. 1990. Influence of previous crops on Rhizoctonia root and crown rot of sugar beet. Plant Dis. 74: 421-425.
28. Russell, G. E. 1978. Some effect of applied sodium and potassium on yellow rust in winter wheat. Ann. Appl. Biol. 90:163-168.

29. Schneider, R. W. 1985. Suppression of Fusarium yellows of celery with nitrate, potassium and chloride. Phytopathology 75:40-48.

30. Schneider, R. W. 1990. Influence of mineral nutrition on Fusarium wilt: A proposed mechanism involving cell water relations. Pages 83 91 in: Fusarium wilt of Banana. R. C. Ploetz, ed. The American Phytopathological Society, St. Paul, MN.

31. Shoa, F. M., and Foy, C. D. 1982. Interaction of soil manganese and reaction of cotton to Verticillium wilt and Rhizoctonia root rot. Commun. Soil. Soc. Plant Anal. 13:21-38.

32. Westerman, D. T., Jackson, T. L., and Moore, D. P. 1971. Effect of potassium salts on ex tractable soil manganese. Soil Sci. Soc. Am. J. 35:43-46.

33. Whitney, E. D., and Duffus, J. E. 1986. Compendium of beet diseases and insects. The American Phytopathological Society, St. Paul, MN.

34. Winter, S. R. 1984. Cropping systems to remove excess soil nitrate in advance of sugar beet production. J. Am. Soc. Sugar Beet Technol. 22:285-290.

35. Younts, S. E., and Musgrave, R. B. 1958. Chemical composition, nutrient absorption and stalk rot incidence of corn as affected by chloride in potassium fertilizer. Agron. J. 62:216-219. 